\title{
Adult Respiratory Distress Syndrome after A Wasp Sting
}

\author{
Arı Sokması Sonrası Yetişkin Solunum Sıkıntısı Sendromu
}

Ahmet Arisoy' , Hilmi Demirkiran², Huseyin Akdeniz³ ${ }^{3}$ Selami Ekin'

\section{Abstract}

Hypersensitivity reactions such as itching, urticaria, angioedema, and anaphylactic reaction are usually seen after a bee or wasp sting. In the literature, rare cases such as myasthenia gravis, peripheral neuritis, encephalomyelitis, optic neuritis, cerebral hemorrhage, myocardial infarction, and nephrotic syndrome have been reported. A 33-year-old female patient was admitted to our emergency department due to the development of dyspnea after a single bee sting. She had no complaints other than dyspnea. On her X-ray, there were bilateral patchy infiltrations. In the blood gases without oxygen, the $\mathrm{pH}$ was 7.3, pO2 was $35 \mathrm{mmHg}$, pCO2 was $30 \mathrm{mmHg}$, and saturation was $75 \%$. Echocardiography findings were normal. She was treated in the intensive care unit under non-invasive mechanical ventilation. She was discharged with full recovery.

Key words: Respiratory Distress Syndrome, Adult, Wasp, Noninvasive Ventilation.

\section{Özet}

Bal arısı veya yaban arısı sokması sonrasında genellikle, kaşıntı, ürtiker, anjiyoödem ve anafilaktik reaksiyon gibi aşırı duyarlılık reaksiyonları görülür. Literatürde, arı sokması sonrası, myastenia gravis, periferik nörit, ensefalomiyelit, optik nörit, beyin kanaması, miyokard infarktüsü ve nefrotik sendrom gibi nadir olgular paylaşılmışıı. Otuz üç yaşındaki bayan hasta tek arı sokması sonrasında nefes darlığı nedeniyle acil servisimize başvurdu. Nefes darlı̆̆ı dışında hiçbir şikâyetleri yoktu. Akciğer grafisinde, bilateral yamalı infiltrasyonları vardı. Oksijensiz alınan kan gazında, $\mathrm{pH} 7,3, \mathrm{paO} 235 \mathrm{mmHg}$, paCO2 $30 \mathrm{mmHg}$ ve saturasyonu \% 75 idi. Ekokardiyografi tamamen normaldi. Yoğun bakımda alındı ve non-invazif mekanik ventilasyon başlanan hasta tedavi sonrası tamamen düzeldi.

Anahtar Sözcükler: Yetişkin solunum sıkıntısı sendromu, Yaban arısı, Noninvazif ventilasyon.
Hypersensitivity reactions such as itching, urticaria, angioedema, and anaphylactic reaction are usually seen after a bee or wasp sting. In the literature, rare cases such as myasthenia gravis, peripheral neuritis, encephalomyelitis, optic neuritis, cerebral hemorrhage, myocardial infarction, and nephrotic syndrome have been reported. However, no cases of adult respiratory distress syndrome (ARDS) have been reported after a wasp sting. Herein, we present a 33-year-old female case of ARDS following a wasp sting.

\footnotetext{
'Department of Chest Diseases, Yüzüncü Yıl University, Faculty of Medicine, Van, Turkey

${ }^{2}$ Department of Anesthesiology and Reanimation, Yüzüncü Y,l University, Faculty of Medicine, Van, Turkey

${ }^{3}$ Department of Radiology, Yüzüncü YIl University, Faculty of Medicine, Van, Turkey
'Yüzüncü Yıl Üniversitesi, Tıp Fakültesi, Göğüs Hastalıkları Anabilim Dalı, Van
${ }^{2}$ Yüzüncü Yıl Üniversitesi, Tıp Fakültesi, Anestezi ve Reaminas- yon Anabilim Dalı, Van
${ }^{3}$ Yüzüncü Yıl Üniversitesi, Tıp Fakültesi, Radyoloji Anabilim Dalı, Van
}

Submitted (Başvuru tarihi): 09.01.2016 Accepted (Kabul tarihi): 08.02.2016

Correspondence (iletişim): Ahmet Arisoy, Department of Chest Diseases, Yüzüncü Yıl University, Faculty of Medicine, Van, Turkey

e-mail:drahmetarisoy@gmail.com 


\section{CASE}

A 33-year-old female patient was admitted to our emergency department with dyspnea after a single wasp sting. She had no other complaints. She did not have swelling in her face or throat, skin rash or itching. Her medical history revealed respiratory distress a year ago; however, she was discharged without being taken to the intensive care unit (ICU).

While in the emergency room, her respiratory rate was 30 bpm, arterial pressure was normal, and saturation measured with a pulse oximeter was $74 \%$. Based on these findings, she was transferred to the ICU. Chest X-ray showed bilateral patchy infiltrations observed (Figure 1). In the blood gases taken without oxygen, $\mathrm{pH}$ was 7.3, $\mathrm{pO}_{2}$ was $35 \mathrm{mmHg}, \mathrm{pCO}_{2}$ was $30 \mathrm{mmHg}$, and the saturation was $75 \%$. The $\mathrm{PO} 2 / \mathrm{FiO} 2$ ratio was 1.66 . Her complete blood count and biochemistry tests were normal. On thoracic computed tomography (CT), there were bilateral areas of patchy ground glass and pleural effusion (Figure 2). Echocardiography findings were completely normal. The patient was suspected with an anaphylactic reaction and methylprednisolone, antihistamines, adrenalin, and NIMV were initiated. While under NIMV, oxygen saturation was around $95 \%$. The patient was followed in the ICU for three days and transferred to the ward when the saturation remained above $90 \%$ with a respiratory rate of $15 \mathrm{bpm}$. At the end of three days, the $X$-ray findings improved to almost normal (Figure 3).

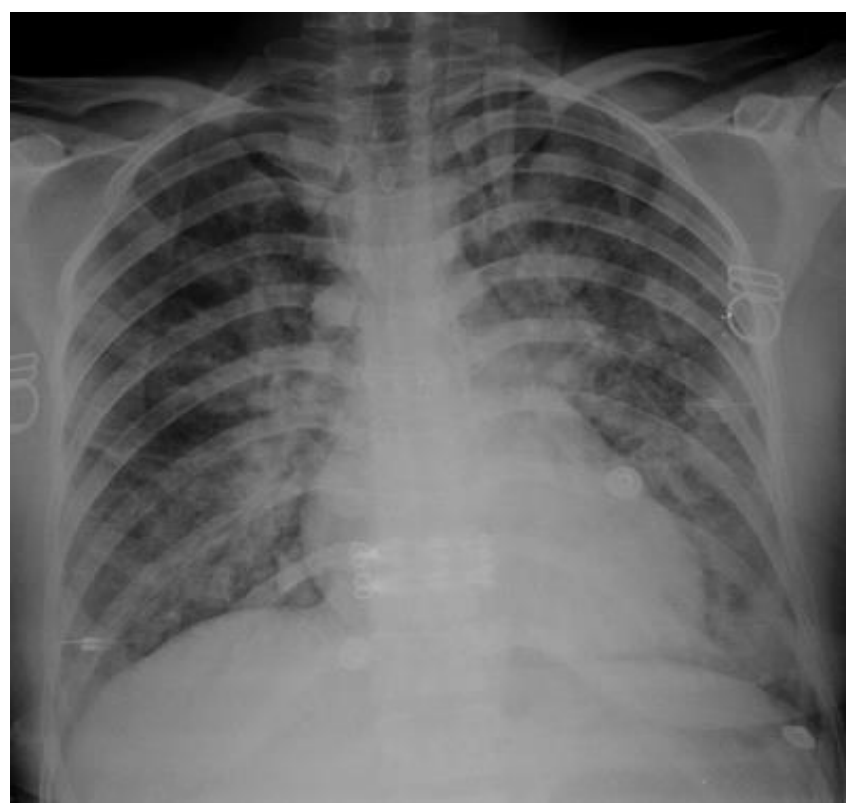

Figure 1: Bilateral patchy infiltrations on chest radiography

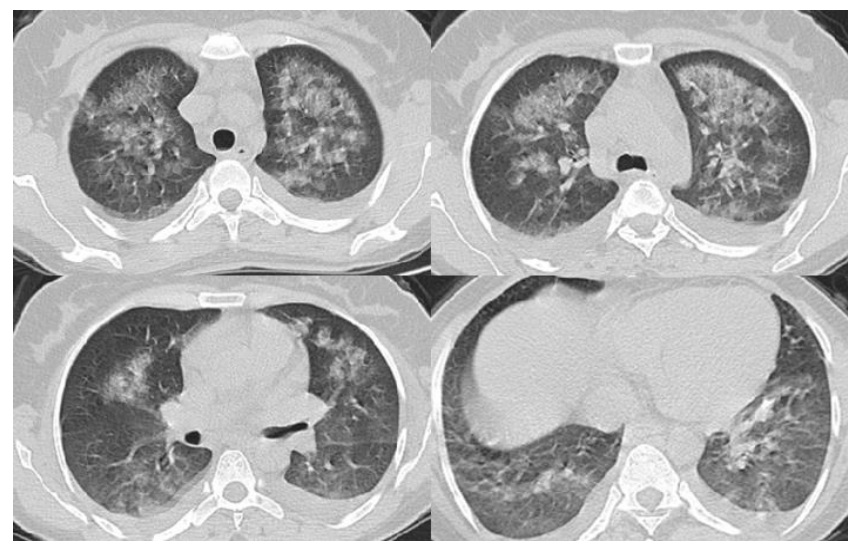

Figure 2: Pleural effusion and patchy ground glass areas on thoracic CT

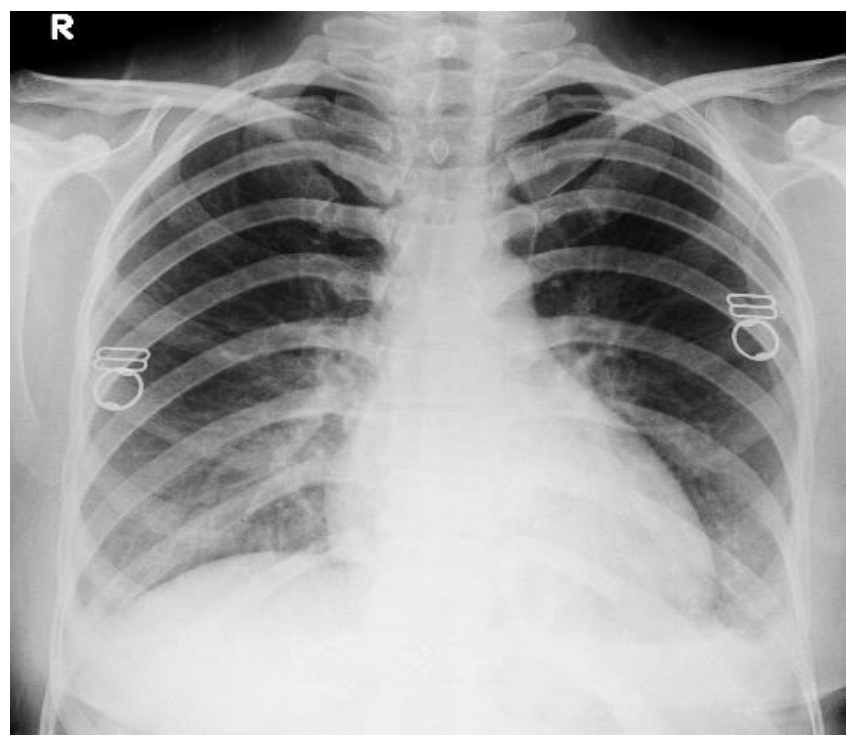

Figure 3: Almost normal chest radiography after treatment

\section{DISCUSSION}

After a wasp sting, the main symptoms include local effects such as edema, erythema and burning, and generalized effects such as itching, urticaria, angioedema, and, in rare cases, anaphylactic reaction (1). Also, rare neurological complications such as myasthenia gravis, peripheral neuritis, encephalomyelitis, optic neuritis, cerebral infarction, Parkinsonism, pontine hematoma, and thalamic and mesencephalic hemorrhage as well as cardiac complications such as myocardial infarction and renal complications such as nephrotic syndrome have been reported (2-11).

More than 50 specific conditions associated with the development of adult respiratory distress syndrome (ARDS) are recognized. The risk for development of ARDS depends on the predisposing clinical condition (i.e., some events are more likely than others to progress to ARDS) but also increases with the number of predisposing factors. Sepsis, bacterial pneumonia, multiple trauma, and aspiration pneumonia are the most common predispos- 
ing factors, accounting all together for more than $70 \%$ of cases; infection is the most frequent cause (12).

While the sting of a single wasp can lead to IgE-mediated anaphylaxis, multiple wasp stings can lead to systemic reactions caused by toxin-mediated cellular injury. Wasp venom contains active amines such as serotonin and histamine and the wasp venom contains kinin and histamin-releasing peptides which may cause severe systemic toxic effects such as hemolysis, coagulopathy, rhabdomyolysis, and acute renal failure (13).

Mej'ıv'elez et al. (13) reported 43 cases of acute renal failure who developed after multiple African bee stings. They showed that renal failure developed after rhabdomyolysis. Bektaş et al. (14) presented two cases who experienced convulsions after a bee sting. In these pediatric cases, convulsion was observed six to eight hours after the bee sting. Neither of these children had a previous history of convulsion. The convulsions did not reoccur during follow-up. In another report, Yoder et al. (15) reported a 60-year-old female patient who developed intracerebral hemorrhage following multiple bee stings. The patient developed nausea, vomiting, and diarrhea, and a general feeling of being unwell two days after the bee stings. Cerebral CT revealed an intracerebral hemorrhage.

In addition, Aydın et al. (16), determined nephrotic syndrome in a three year old patient who presented with complaints of swelling around the eyes and face and edema of the body and particularly the legs eight days after a bee sting. In a 65-year-old patient reported by Mathew et al (17), acute myocardial infarction, severe rhabdomyolysis, and angioedema were detected after multiple bee stings. Yanagawa et al. (18) reported that the skin necrosis developing after a wasp sting could be an indicator of systemic toxic effects.

\section{CONCLUSION}

However, there is no reported case of adult respiratory distress syndrome developing after a wasp sting. Reported cases are the ones of respiratory insufficiency in the form of laryngeal edema, angioedema, or anaphylactic shock. In our case, ARDS developed after the single sting of a wasp on the patients arm. The patient had no complaints other than dyspnea. She had no complaints such as rash, swelling or itching. Respiratory distress developed approximately 30 min after the sting and a diagnosis of ARDS was made in the emergency room. Therefore, the patient was transferred to the ICU. Her medical and NIMV treat- ment was arranged in the ICU. The patient completely recovered after treatment.

\section{CONFLICTS OF INTEREST}

None declared.

\section{AUTHOR CONTRIBUTIONS}

Concept - A.A., H.D., H.A., S.E.; Planning and Design A.A., H.D., H.A., S.E.; Supervision - A.A., H.D., H.A., S.E.; Funding -; Materials - A.A.; Data Collection and/or Processing - S.E., H.A.; Analysis and/or Interpretation A.A.; Literature Review - H.D.; Writing - A.A.; Critical Review - S.E., H.D.

\section{YAZAR KATKILARI}

Fikir - A.A., H.D., H.A., S.E.; Tasarım ve Dizayn - A.A., H.D., H.A., S.E.; Denetleme - A.A., H.D., H.A., S.E.; Kaynaklar -; Malzemeler - A.A.; Veri Toplama ve/veya Issleme - S.E., H.A.; Analiz ve/veya Yorum - A.A.; Literatür Taraması - H.D.; Yazıyı Yazan - A.A.; Eleştirel İnceleme S.E., H.D.

\section{REFERENCES}

1. Day JM. Death due to cerebral infarction after wasp stings. Arch Neurol 1962; 7:184-6. [CrossRef]

2. Ashworth B. Encephalopathy following a sting. J Neurol Neurosurg Psychiatry 1964; 27:542-6. [CrossRef]

3. Boz C, Velioglu S, Ozmenoglu M. Acute disseminated encephalomyelitis after bee sting. Neurol Sci 2003; 23:313-5. [CrossRef]

4. Brumlik J. Myasthenia gravis associated with wasp sting. JAMA 1976; 235:2120-1. [CrossRef]

5. Crawley F, Schon F, Brown MM. Cerebral infarction: a rare complication of wasp stings. I Neurol Neurosurg Psychiatry 1999; 66:550-1. [CrossRef]

6. Goldstein NP, Rucker W, Klass DW. Encephalopathy and papilledema after bee stings. JAMA 1964; 188:1083-4. [CrossRef]

7. Maltzman JS, Lee AG, Miller NR. Optic neuropathy occurring after bee and wasp sting. Ophtalmology 2000; 107: 193-5. [CrossRef]

8. Remes-Troche JM, Tellez-Zenteno JF, Rojas-Serrano J, Senties-Madrid H, Vega-Boada F, Garcia-Ramos G. Thalamic and mesencephalic hemorrhages after multiple honeybee stings: a life-threatening apitherapy complication. Eur Neurol 2003; 49:188-9. [CrossRef]

9. Riggs $J E$, Ketonen $L M$, Bodensteiner JB, Benesch CG. Wasp sting-associated cerebral infarction: a role for 
cerebrovascular sympathetic innervation. Clin Neuropharmocol 1993; 16: 362-5. [CrossRef]

10. Schiffman JS, Tang RA, Ulysses E, Dorotheo N, Singh SS, Bahrani HM. Bilateral ischemic optic neuropathy and stroke after multiple bee stings. BR J Ophthalmol 2004; 88:1596-8.

11. Starr JC, Brasher GW. Wasp sting anaphylaxis with cerebral infarction. Ann Allergy 1977; 39: 431 -3.

12. Korman SH, Jabbour S, Harari MD. Multiple hornet (Vespa orientalis) stings with fatal outcome in a child. J Paediatr Child Health 1990; 26:283-5.

13. Mejía Vélez $G$. Acute renal failure due to multiple stings by Africanized bees. Report on 43 cases. Nefrologia 2010; 30:531-8. [CrossRef]

14. Bektas S, Peker E, Cağan E, Doğan M, Kaya A, Sal E ve ark. Arı sokmasını takiben konvulziyon geliştiren iki olgu Sunumu. Tıp Araştırmaları Dergisi 2010; 8:131-3.
15. Yoder J, Lloyd A, Tilney PV, McKenna DP. Intracerebral hemorrhage following multiple bee stings. JAAPA 2013; 26:1097-101. [CrossRef]

16. Aydın M, Karakuş N, Akarsu S, Demirol M. Nephrotic syndrome in a child following a bee sting. J Firat Med $2006 ; 11: 71-2$

17. Mathew A, Chrispal A, David T. Acute myocardial injury and rhabdomyolysis caused by multiple bee stings. J Assoc Physicians India 2011 ; 59:518-20.

18. Yanagawa Y, Morita K, Sugiura T, Okada Y. Cutaneous hemorrhage or necrosis findings after Vespa mandarinia (wasp) stings may predict the occurrence of multiple organ injury: a case report and review of literature. Clin Toxicol (Phila) 2007; 45:803-7. 